\title{
Relationship between Degree of Enophthalmos and Orbital Volume Measured with Computed Tomography in Isolated Blowout Fractures of the Orbit
}

\author{
Joon Jeon ${ }^{1}$, Kyong Myong Chon ${ }^{2}$, Tae Young Jung ${ }^{1}$, \\ Woong Jae Noh ${ }^{1}$, Jae Hwan Kwon ${ }^{1}$ and Young Ho Kim ${ }^{1}$ \\ ${ }^{\prime}$ Department of Otolaryngology-Head and Neck Surgery, Maryknoll Medical Center, Busan, ; and \\ ${ }^{2}$ Department of Otolaryngology-Head and Neck Surgery, Pusan National University School of Medicine, Busan, Korea
}

\author{
안와 외향골절에서 전산화단층촬영을 통한 안와의 용적측정과 안구함몰 정도와의 관계 비교 \\ 전 준 $^{1} \cdot$ 전경명 ${ }^{2} \cdot$ 정태영 $^{1} \cdot$ 노웅재 $^{1} \cdot$ 권재환 $^{1} \cdot$ 김영호 $^{1}$ \\ 메리놀병원 이비인후과, ${ }^{1}$ 부산대학교 의학전문대학원 이비인후과학교실 ${ }^{2}$
}

Received February 8, 2009 Revised August 17, 2009 Accepted August 24, 2009

Address for correspondence Kyong Myong Chon, $\mathrm{MD}, \mathrm{PhD}$ Department of OtolaryngologyHead and Neck Surgery, Pusan National University School of Medicine, 305 Gudeok-ro, Seo-gu, Busan 602-739, Korea Tel +82-51-461-2205 Fax +82-51-461-0297

E-mail hands-jung@hanmail.net
Background and Objectives We investigated the relationship between the degree of enophthalmos and the volume of herniated orbital tissue measured from computed tomography scan in the isolated blowout fractures of orbital wall.

Subjects and Method In this retrospective study, 100 patients with isolated blowout fractures were evaluated. We classified them into 4 groups according to the site of fracture (medial and inferior) and the presence of symptoms like diplopia and limitation of ocular motility, which needs an operation. The volume of orbit and herniated orbital tissue has been measured by computed tomography scans using three-dimensional reconstruction technique, and the degree of enophthalmos was evaluated with Hertel's ophthalmometer. We compared the volume from which we got from the computed tomography scan, the degree of enophthalmos and the presence of symptoms to figure out the mutual relation between the groups.

Results In the case of medial blowout fracture group, the volume of herniated orbital tissues increased significantly with the presence of symptoms and was in proportion to the extent of enophthalmos $(p<0.05)$. The volume expansion of orbit associated with $2 \mathrm{~mm}$ of enophthalmos as calculated by the regression curve was $3.1 \mathrm{ml}$ or $12.8 \%$ in the no-symptoms groups. Finally, in the case of inferior blowout fracture group, there was no evidence of mutual relation.

Conclusion These results suggest that surgical intervention is required even though there isn't any symptom for medial blowout fractures, especially when the orbit volume is more than $12.8 \%$. In cases of inferior blowout fractures, a close follow-up is needed even though the extent of fracture is small. Korean J Otorhinolaryngol-Head Neck Surg 2009;52:810-5

Key Words Blowout fracture $\cdot$ Computed tomography $\cdot$ Volume of orbit.
서 론

안와 외향골절은 안면부에 미치는 둔상에 의해 발생하는 외상 중 흔한 손상이다. 안와 외향골절의 진단 및 수술에 대한 판단은 안구운동장애, 복시, 안구함몰 등 임상증상의 정도, 전산화단층촬영상 골절의 범위 그리고 외과의의 임상
적인 경험에 따라 이루어진다. ${ }^{1)}$ 만약 수술이 지연되면 골절 의 부전유합은 물론 연조직의 섬유화로 인하여 조기에 수술 을 시행한 경우보다 결과가 좋지 못하므로 늦어도 수상 후 7 14일 이내에 치료하는 것이 바람직하다. ${ }^{2)}$

안구의 함몰은 정상측에 비해 2 3 $\mathrm{mm}$ 이상의 차이가 있 을 경우 미용학적인 문제를 일으킨다고 알려져 있지만, ${ }^{3)}$ 수 
상 초기에는 안와내 연부조직의 부종으로 안구함몰이 잘 나 타나지 않고, 시간이 지나면서 부종이 소실되면 안구함몰이 확연해지므로 ${ }^{4,5)}$ 수상 초기에 안구함몰의 정도로 수술의 여 부를 결정하는 것은 쉽지 않다. 안구함몰의 원인으로는 외 향골절로 인한 안와의 용적 증가, 안와 내 연부조직의 괴사 및 섬유화, 안와 내 조직의 골절부위를 통한 탈출, 안구를 지 지하는 인대의 손상 및 전위 등이 있다. 그리고 정상 안와와 외향골절에 의한 탈출조직을 포함한 외상 후 안와의 용적 증 가에 의한 영향이 가장 크다고 알려져 있다. ${ }^{3,6)}$ 그러므로 수 상 초기에 전산화단층촬영을 이용하여 수상 후 안와용적의 증가 정도를 측정하여 향후 발생할 안구함몰의 정도를 예측 할 수 있다면 수술 여부는 물론 수술의 시기를 결정하는 데 도움을 줄 수 있다.

이에 저자는 안와 외향골절 환자들을 대상으로 수상 초기 에 안구함몰의 정도를 예측하고 수술의 적응증을 결정하기 위해 전산화단층촬영 소견을 이용하여 안와 및 탈출부위의 용적을 측정하고 이를 안구함몰의 정도와 비교하여 서로 유 의한 관계가 있는지 검토하였다.

\section{대상 및 방법}

\section{대 상}

1996년 1월부터 2008년 4월까지 메리놀병원 이비인후 과에서 순수 안와 외향골절로 진단한 115 명(남자 94명, 여 자 21명)의 환자를 대상으로 전산화단층촬영 및 의무기록 을 후향적으로 분석하였다. 환자의 연령은 4 74세로 평균 연령은 33.0 세였다. 이 중 17 세 이하의 환자 10 명을 연령에 따른 안와의 크기 변화로 인한 오차를 줄이기 위해 제외하 였으며, 수상 후 10 일 이후에 전산화단층촬영을 시행한 5명 의 환자들 또한 제외하였다. 상기 15 명을 제외한 100 명의 환자 중 64 명이 안와 내벽골절(좌: 39 , 우: 25), 36 명은 안 와 하벽골절(좌: 22 , 우: 14)로 진단되었다. 안와 하벽골절 환 자 중 31 명은 비외 접근법을 이용한 재건술을 시행하였으며 5 명은 경과를 관찰하였다. 안와 내벽골절 환자 중 46 명은 내시경을 이용한 비내 재건술을 시행하였고 나머지 18 명은
경과를 관찰하였다.

안와 외향골절 환자들을 골절 부위와 복시 및 안구운동장 애 증상의 유무에 따라 4 개의 군으로 나누었다. I군은 안와 내 벽골절이 있으면서 증상이 있는 군으로 18 명(남: 13 , 여: 5) 이었으며 평균연령은 34.6세였다. II군은 안와 내벽골절이 있으면서 증상이 없는 군으로 46명 (남: 37 , 여: 9)이었으 며 평균연령은 38.5세였다. III군은 안와 하벽골절이 있으 면서 증상이 있는 군으로 22명 (남: 19 , 여: 3)이었으며 평 균연령은 31.0 세였다. IV군은 안와 하벽골절이 있으면서 증상이 없는 군으로 14 명 (남: 13 , 여: 1)이었으며 평균연 령은 29.0세였다(Table 1).

\section{방 법}

안와 및 탈출부위 용적 측정은 전산화단층촬영 (Aquilion TSX-101A, Toshiba Medical System Corp, Japan)으로 $2 \mathrm{~mm}$ 의 절편 두께로 관상면과 횡단면을 촬영하였으며, 수 상 후 전산화단층촬영까지의 기간은 수상 당일에서 9일까지 로 평균 1.3일이었다. 모든 영상을 high-resolution osseous window level로 변환하였고, Vitrea 프로그램(Vitrea ${ }^{\mathrm{TM}}$ ) ver.3.4, Vital Image)을 이용하여 3차원 영상으로 재구성 하였다. 안와 내벽골절의 경우에는 안와의 내측이 나타난 모 든 횡단면의 스캔 데이터를, 안와 하벽골절의 경우에는 관상 면의 스캔 데이터를 사용하였다. 안와벽을 따라 cursor를 움 직여 측정할 부위의 경계를 결정하였다(Figs. 1 and 2). 횡 단면의 스캔 데이터에서는 안와 앞쪽 경계를 안와연의 내측 과 외측을 일직선으로 연결한 직선까지, 뒤쪽 경계는 시신 경관(optic canal) 경계부까지를 3차원 영상으로 나타내어

\section{Table 1. Subjects}

\begin{tabular}{lccc}
\hline Fracture types & Cases & Age (year) & Sex $(\mathrm{M}: \mathrm{F})$ \\
\hline Medial & 64 & $18-74(37.4 \pm 12.7)$ & $50: 14$ \\
$\quad$ Group I & 18 & $18-63(34.6 \pm 12.8)$ & $13: 5$ \\
Group II & 46 & $18-74(38.5 \pm 12.7)$ & $37: 9$ \\
Inferior & 36 & $18-69(30.0 \pm 11.0)$ & $32: 4$ \\
Group III & 22 & $18-69(31.0 \pm 12.3)$ & $19: 3$ \\
Group IV & 14 & $21-48(29.0 \pm 7.2)$ & $13: 1$ \\
\hline Total & 100 & $18-74(34.8 \pm 12.4)$ & $82: 18$ \\
\hline
\end{tabular}

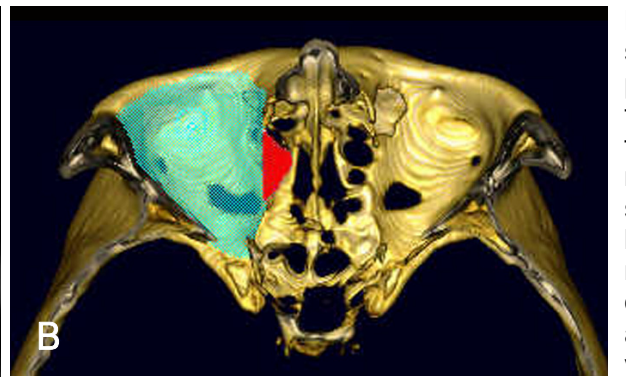

Fig. 1. Three-dimensional reconstruction of axial computed tomography scan. Blue line means cursor tracing of bony orbital margin used for measuring volume of orbit, and red striped area shows herniated tissue of orbit (expansion volume of orbit) (A). In inferior view of three-dimensional reconstructed skull and orbit, blue area shows orbital volume and red area shows herniated obital volume (B). 

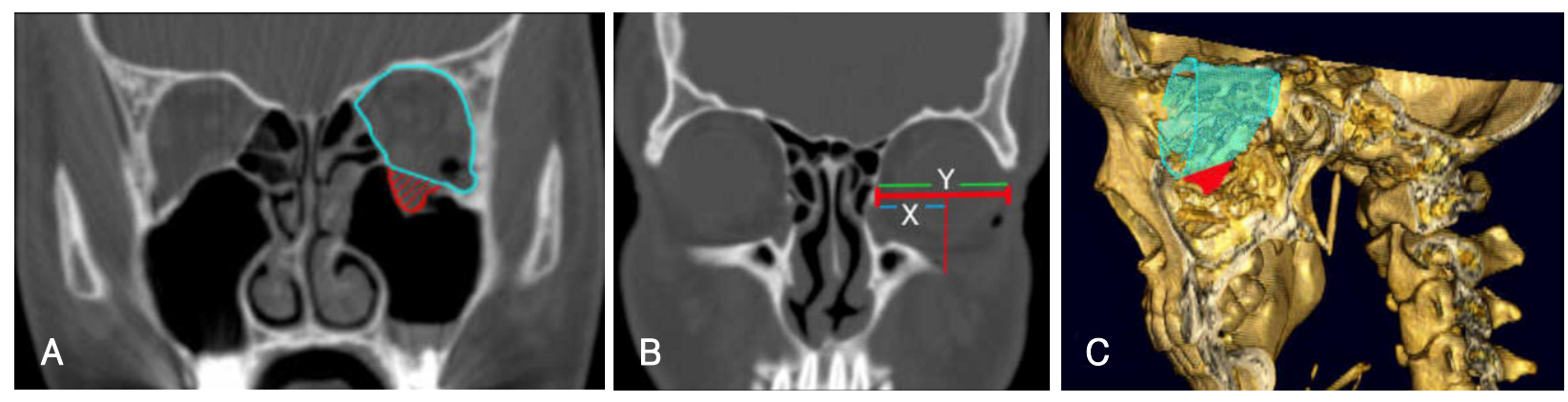

Fig. 2. Three-dimensional reconstruction of coronal computed tomography scan. Blue line means cursor tracing of bony orbital margin used for measuring volume of orbit, and red striped area shows herniated tissue of orbit (expansion volume of orbit) (A). Over $50 \%$ (X) of inferior orbital border $(\mathrm{Y})$ is shown on the anterior margin of bony orbit $(\mathrm{B})$. In lateral view of three-dimensional reconstructed skull and orbit, blue area shows orbital volume and red area shows herniated obital volume (C).

Table 2. Relationship between calculated value of orbital volume, herniated volume and the degree of enophthalmos in each group

\begin{tabular}{lcccc}
\hline Fracture types & Orbit Vol. $(\mathrm{mL})$ & Herniated Vol. $(\mathrm{mL})$ & Herniated Vol. $(\%)$ & Enopthalmos $(\mathrm{mm})$ \\
\hline Medial & $17.8-29.1(23.8 \pm 2.6)$ & $0.2-4.0(1.9 \pm 1.0)$ & $0.7-20.2(8.0 \pm 4.3)^{\dagger}$ & $3.7-17.8(9.5 \pm 4.6) *$ \\
Group I & $20.3-28.4(23.2 \pm 2.3)$ & $0.8-4.0(2.2 \pm 1.1)$ & $0.7-20.2(7.4 \pm 4.1)^{*}$ & $0-2(1.2 \pm 0.9)$ \\
Group II & $17.8-29.1(24.0 \pm 2.7)$ & $0.2-4.0(1.8 \pm 0.9)$ & $1.0-18.5(9.2 \pm 4.7)^{\dagger}$ & $0-4(1.2 \pm 1.0)$ \\
Inferior & $16.6-29.6(23.6 \pm 3.1)$ & $0.3-4.0(2.1 \pm 1.1)$ & $0-4(1.1 \pm 1.0)$ \\
Group III & $16.6-29.1(23.9 \pm 3.3)$ & $0.3-4.0(2.2 \pm 1.1)$ & $0-18.5(9.5 \pm 4.8)^{\dagger}$ & $0-4(1.1 \pm 1.0)$ \\
Group IV & $19.3-29.6(23.1 \pm 2.8)$ & $0.5-3.7(2.0 \pm 1.0)$ & $0.7-20.0(8.4 \pm 4.4)^{\dagger}$ & $0-4(1.2 \pm 0.9)$ \\
\hline Total & $16.6-29.6(23.7 \pm 2.8)$ & $0.2-4.0(2.0 \pm 1.0)$ &
\end{tabular}

안와용적을 $\mathrm{mL}$ 단위로 측정하였다. 관상면의 스캔 데이터 에서는 안와하연의 $50 \%$ 가 나타나는 면을 앞쪽 경계로 하고 뒤쪽 경계는 안와의 꼭지점으로 하여 3 차원 영상으로 나타내 어 안와용적을 $\mathrm{mL}$ 단위로 측정하였다. 상안와열 (superior orbital fissure), 하안와열(inferior orbital fissure), 누선와 (lacrimal fossa), 시신경관은 경계에서 제외하였다. 그리고 안와 조직의 탈출용적 및 안와용적에 대한 측정치를 이용하 여 안와용적에 대한 안와 조직의 탈출용적비(안와용적의 증 가율)를 백분율로 구하였다.

안구함몰의 정도는 Hertel의 안구돌출계를 사용하여 $1 \mathrm{~mm}$ 단위로 측정하였다. 수상 후 안구돌출 계측까지의 기간은 3 일 에서 18일 사이로 술 전 마지막으로 측정한 값을 기준으 로 삼았고 이는 평균 10.0 일이었다.

선형회귀법과 t-test를 이용하여 $5 \%$ 유의수준으로 통계 분석을 시행하였다.

\section{결 과}

각 군별 안와 조직의 탈출용적, 안와용적 및 안구함몰 정도

I군의 경우 안와 조직의 탈출용적은 평균 $2.2 \pm 1.1 \mathrm{~mL}$ (0.8 4) 였으며, 안와용적은 평균 $23.2 \pm 2.3 \mathrm{~mL}(20.3 \sim$ 28.4)로 안와용적의 증가율은 평균 $9.5 \pm 4.6 \%$ (3.7 17.8\%) 였고, 안구함몰 정도는 평균 $1.1 \pm 0.8 \mathrm{~mm}(0 \sim 2)$ 였다.
II군의 경우 안와 조직의 탈출용적은 평균 $1.8 \pm 0.9 \mathrm{~mL}$ (0.2 4) 였으며, 안와용적은 평균 $24.0 \pm 2.7 \mathrm{~mL}(17.8 \sim 29.1)$ 로 안와용적의 증가율은 평균 $7.4 \pm 4.1 \%(0.7 \sim 20.2)$ 였고, 안구함몰 정도는 평균 $1.2 \pm 1.0 \mathrm{~mm}(0 \sim 4)$ 였다.

III군의 경우 안와 조직의 탈출용적은 평균 $2.2 \pm 1.1 \mathrm{~mL}$ (0.3 4.0) 였으며, 안와용적은 평균 $23.9 \pm 3.3 \mathrm{~mL}(16.6$ 29.1)로 안와용적의 증가율은 평균 9.5 $4.8 \%$ (1.0 18.5)이 었고, 안구함몰 정도는 평균 $1.1 \pm 1.0 \mathrm{~mm}(0 \sim 4)$ 였다.

$\mathrm{IV}$ 군의 경우 안와 조직의 탈출용적은 평균 $2.0 \pm 1.0 \mathrm{~mL}$ (0.5 3.7) 였으며, 안와용적은 평균 $23.1 \pm 2.8 \mathrm{~mL}(19.3$ 29.6)로 안와용적의 증가율은 평균 $8.7 \pm 4.5 \%$ (2.6 17.9)이 고, 안구함몰 정도는 평균 $1.0 \pm 1.0 \mathrm{~mm}(0 \sim 3 \mathrm{~mm})$ 였다(Table 2).

각 군별 안와 조직의 탈출용적, 안구함몰 정도 및 안와용 적의 증가율에 대한 통계

안와 내벽골절 환자의 경우 I군과 II군에서 모두 전산화 단층촬영으로 측정한 안와 조직의 탈출용적과 안구함몰 정 도가 선형회귀분석상 의미 있는 비례관계를 보였다. 안와용 적의 증가비율 또한 I군과 II군 모두에서 안구함몰 정도와 의미 있는 비례관계를 나타내었다 $(p<0.05)$.

안와 하벽골절 환자의 경우는 III군과 IV군 모두 안와 조직의 탈출용적과 안와용적의 증가율에서 안구함몰의 정 

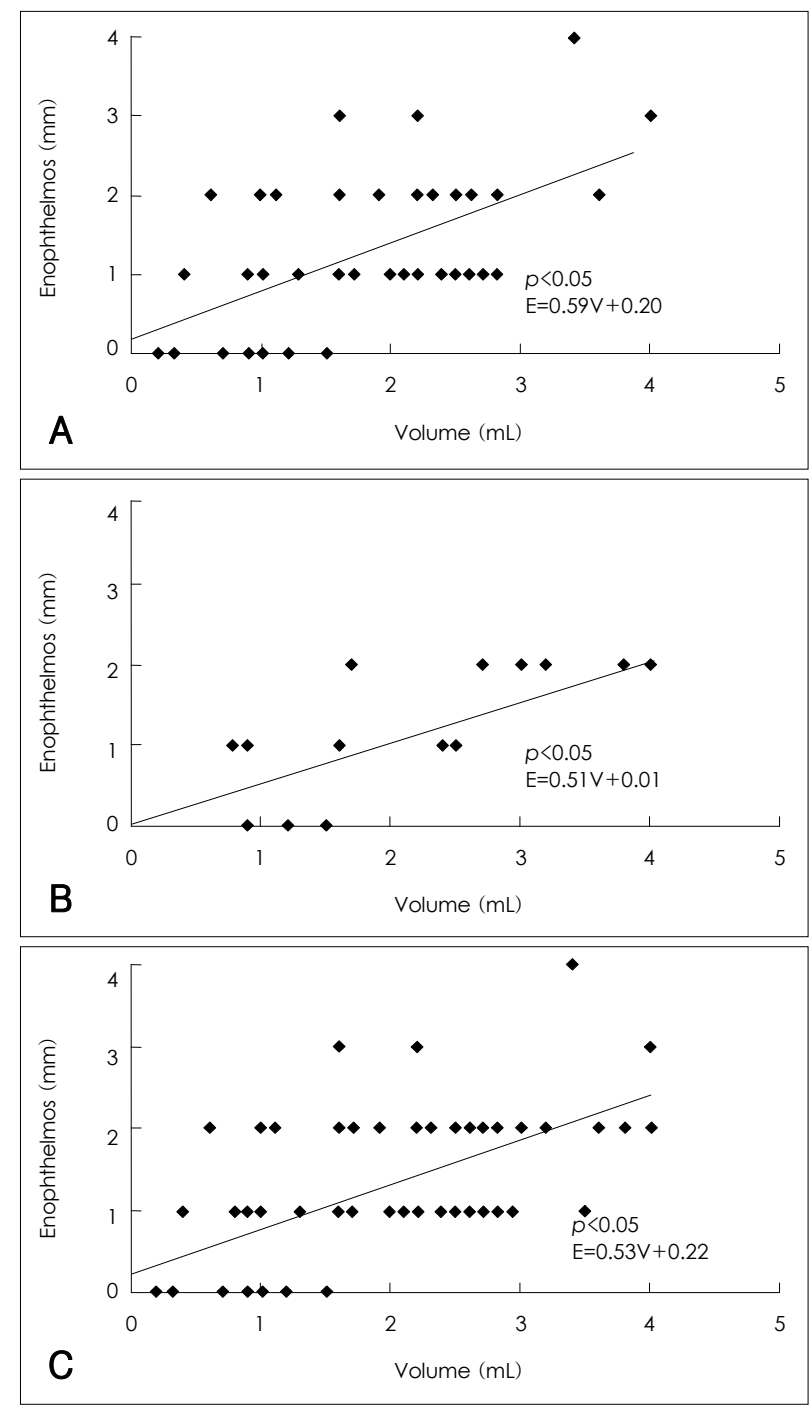

Fig. 3. Positive correlation between volume of herniated orbital tissue and enophthalmos. In all medial blow out fracture gruop the volume of herniated orbital tissue that causes enophthalmos of $2 \mathrm{~mm}$ is $3.4 \mathrm{~mL}$, as calculated from the regression curve (A). In symptom positve group this is $3.9 \mathrm{~mL}$ (B). In symptom negative group this is $3.1 \mathrm{~mL}(\mathrm{C})$. E: enophthalmos, $\mathrm{V}$ : volume of herniated orbital tissue $(\mathrm{mL})$.

도와 의미 있는 비례관계가 없었다 $(p>0.05)$.

안와 내벽골절 환자 전체의 경우 선형회귀분석상 $\mathrm{E}=0.5 \times$ $\mathrm{V}+0.22, \mathrm{E}=0.12 \times \mathrm{I}+0.22(\mathrm{E}$ : 안구함몰의 정도, $\mathrm{V}:$ 안와 조직의 탈출용적, I: 안와용적의 증가율)의 수식을 도출하 였으며, 각 군을 살펴보면 I군의 경우 $\mathrm{E}=0.51 \times \mathrm{V}+0.01$, $\mathrm{E}=0.12 \times \mathrm{I}+0.01, \mathrm{II}$ 군의 경우 $\mathrm{E}=0.59 \times \mathrm{V}+0.20, \mathrm{E}=0.14$ $\times \mathrm{I}+0.21$ 의 수식을 도출할 수 있었다(Figs. 3 and 4).

\section{고 찰}

안와 외향골절은 안면부 둔상에 의한 충격이 안와내 연부
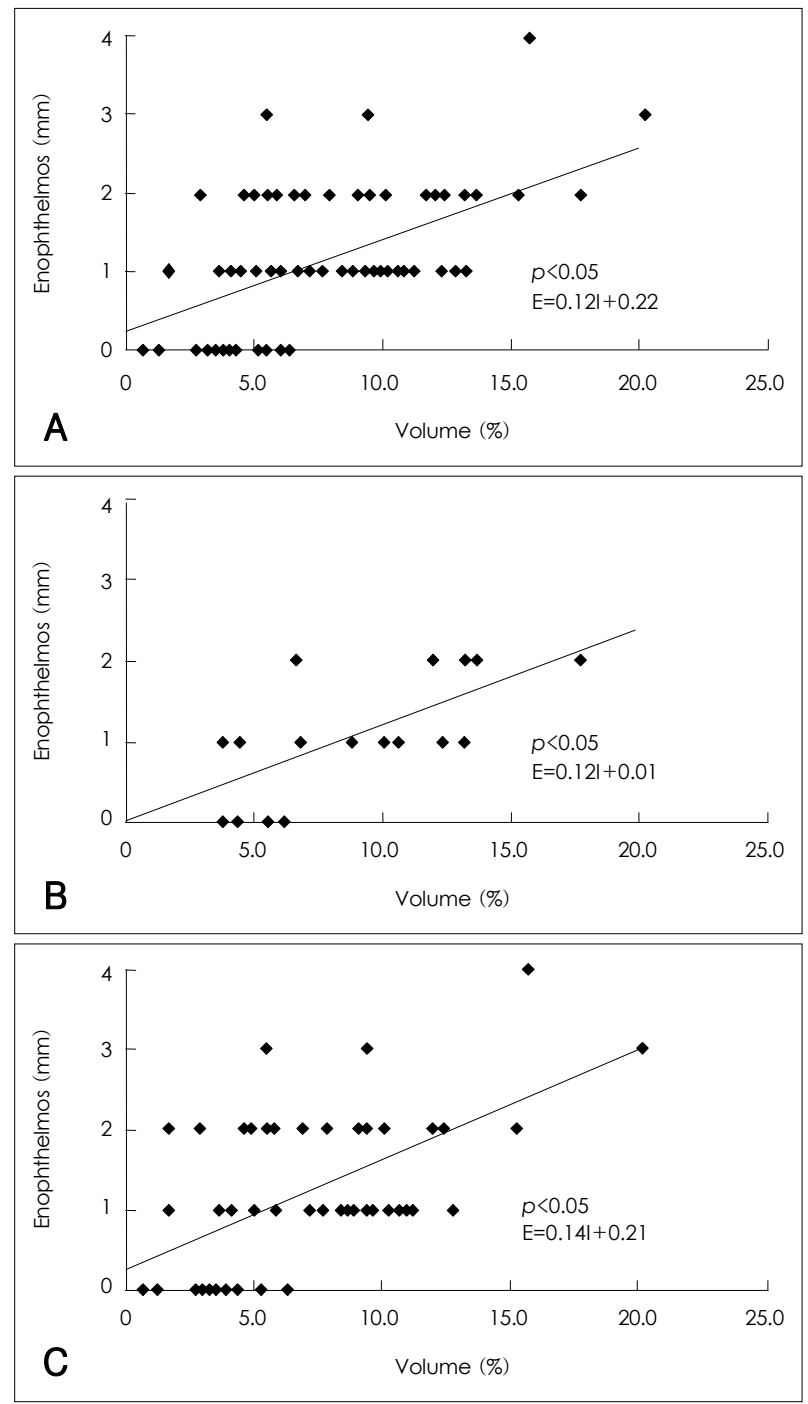

Fig. 4. Positive correlation between the proportion of increased orbital volume (\%) and enophthalmos. In all medial blow out fracture group, the proportion of increased orbital volume that causes enophthalmos of $2 \mathrm{~mm}$ is $14.8 \%$, as calculated from the regression curve (A). In symptom positve group this is $16.6 \%$ (B). In symptom negative group this is $12.8 \%$ (C). E: enophthalmos, I: proportion of increased orbital tissue (\%).

조직에 전달되면서 안와내 압력이 상승되어, 안와벽 중에서 약한 부위에 골절이 생겨, 안와의 연조직 내용물이 골절편 사 이로 빠져나가는 질환이다. 이 질환의 호발부위는 안와 하벽 과 내벽이며 임상 소견 및 이학적 검사, 단순 방사선검사를 통하여 어느 정도 의심할 수 있으나 전산화단층촬영으로 확 진할 수 있다.

수술의 적응증은 안구운동의 기계적 제한이 있거나, 2 주 이내에 복시가 소실되지 않는 경우, $2 \mathrm{~mm}$ 이상의 안구함몰 이 있거나, 방사선학적으로 광범위한 골절이 확인될 때이 다. ${ }^{7.8)}$ 수술의 시기에 대해서는 논란이 있지만, 수술이 지연 되는 경우 골절의 부전유합과 연조직의 섬유화로 인하여 조 
기에 수술을 시행한 경우보다 결과가 좋지 못하므로, 일반적 으로 안와 주위의 종창이 충분히 소실되는 수상 후 7 에서 14 일 사이에 수술을 시행한다. ${ }^{2)}$ 수술의 적응이 되는 심한 복 시와 안구운동장애가 나타나는 경우 수술 여부를 판단함에 어려움이 없으나, 상기 증상이 나타나지 않는 경우에는 향후 안구함몰이 얼마나 나타날 것인지 예측하는 것이 중요하다. 그러나 수상 초기에는 안와내 연부조직의 부종으로 안구함몰 이 잘 나타나지 않고 오히려 안구돌출을 보이는 경우도 있으 며 시간이 지나야 부종이 소실되고 안구함몰이 나타난다. ${ }^{4,5)}$ 그러므로 조기에 수술 여부를 결정하기 위해서는 향후의 안 구함몰을 예측할 수 있는 요소가 필요하며, Manson 등은 은 안구함몰의 정도는 안와 외향골절로 인하여 안와용적이 넓 어지므로 일어나는 안와 내용물이 전위된 양과 직접적으로 비례한다고 주장하였다. 따라서 전산화단층촬영을 이용하 여 안와 외향골절의 정도를 판단하고 안와용적의 증가를 측 정하는 것은 향후 안구함몰의 정도를 예측하고 치료를 결정 함에 있어 도움이 될 것이다.

전산화단층촬영에서 안와 골절의 면적 및 용적을 측정하 기 위해서 다양한 방법들이 시도되었다. Ploder 등')은 골절 부위의 폭과 높이를 관상면에서 측정하여 탈출한 안와조직 의 면적 및 용적을 구하였으며 Jin 등이은 탈출부위를 타원 형으로 가정하고 폭과 높이, 전후 길이를 측정하여 탈출한 안 와조직의 면적과 용적을 구하였다. 본 연구에서는 Bite 등1) 이 사용한 전산화단층촬영 영상을 3 차원으로 구성하여 용적 을 측정하는 방법을 선택하였다. Ploder 등9) 과 Jin 등 ${ }^{10)}$ 의 방법은 안와 및 탈출 조직의 용적을 직접적으로 측정할 수 없을 경우에 근사치를 얻을 수 있겠으나, 최근에는 단층촬영 상을 컴퓨터를 이용하여 3 차원으로 재구성하여 직접적으로 용적의 측정이 가능해졌다. 또 수상 안와의 용적에서 정상 안 와의 용적을 감하여 탈출 부위의 용적을 구할 경우 양안의 용적 차이가 7 8\%까지 있을 수 있으므로 ${ }^{12,13)}$ 오차가 생기 게 되지만 직접 용적을 측정하는 경우 이에 따른 오차를 줄 일 수 있다.

본 연구에서는 안와 골절의 부위와 수술의 적응증의 여부 에 따라 환자를 분류하고 골절부위와 증상 유무에 따른 안 와용적의 증가율 차이, 안와 조직의 탈출용적과 안구함몰 정 도의 상관관계, 그리고 안와용적의 증가율과 안구함몰 정도 의 상관관계를 알아보았다. 안와용적의 증가율에 대해서는 안와 내벽골절과 하벽골절 간에 차이가 없었다. 그리고 내 벽골절의 경우는 증상이 있는 군에서 안와용적의 증가가 의 미 있게 크게 나타났으나 $(p<0.05)$, 하벽골절의 경우는 의미 있는 차이를 보이지 않아, 내벽골절에서 안와용적의 증가가 안구함몰 이외의 증상에도 영향을 미친다는 것을 알 수 있
었다. 안구함몰과의 관계에 있어서는 안와 내벽골절의 경우 안와 조직의 탈출용적과 안와용적의 증가율 모두 증상이 있 는 군과 증상이 없는 군에서 비례관계를 나타내었다.

본 연구에서 회귀분석을 이용하여 도출한 수식에 따르면 안와 내벽골절의 경우 안와의 용적이 $3.4 \mathrm{~mL}$ 또는 $14.8 \%$ 증가할 때 $2 \mathrm{~mm}$ 의 안구함몰이 있을 것으로 보이며, $1.9 \mathrm{~mL}$ 또는 $8.3 \%$ 증가함에 따라 $1 \mathrm{~mm}$ 씩 안구함몰이 심해질 것 으로 생각한다. 증상이 있는 군은 안와의 용적이 $3.9 \mathrm{~mL}$ 또 는 $16.6 \%$ 증가할 때 $2 \mathrm{~mm}$ 의 안구함몰을 보일 것으로 예 상되며, $2.0 \mathrm{~mL}$ 또는 $8.3 \%$ 증가함에 따라 $1 \mathrm{~mm}$ 의 안구함 몰을 나타낼 것으로 생각한다. 증상이 없는 군에서는 안와용 적 증가가 $3.1 \mathrm{~mL}$ 또는 $12.8 \%$ 일 때 $2 \mathrm{~mm}$ 의 안구함몰을 보일 것으로 예상되며, $1.7 \mathrm{~mL}$ 또는 $7.1 \%$ 당 $1 \mathrm{~mm}$ 의 안구 함몰이 있을 것으로 생각한다. 측정한 안와용적의 평균값으 로 생각할 때는 두 값의 차이가 심하지 않지만, 안와용적이 개인별로 편차가 있으므로 $(16.6 ~ 29.6 \mathrm{~mL})$ 단순한 탈출용 적보다는 상대적인 안와용적의 증가율로 향후 안구함몰의 정도를 판단하는 것이 합리적일 것이다.

안와 하벽골절의 경우 본 연구에서는 안와 조직의 탈출용 적과 안와용적의 증가율 모두 수술의 절대적 적응증의 유무 와 관계없이 안구함몰 정도와 상관관계를 보이지 않았다. 특 히 탈출용적이 $0.5 \mathrm{~mL}$ 로 안구용적의 $3.6 \%$ 임에도 불구하고 $3 \mathrm{~mm}$ 의 안구함몰을 보이는 경우도 있어 안와 하벽골절의 경우 안와 내벽골절과 달리 안구함몰의 정도가 안와의 용적 증가에 단순히 비례하지는 않음을 보여준다. 즉, 안와의 용 적 증가 이외의 연조직의 괴사 및 섬유화, 안구를 지지하는 인대의 손상 및 전위와 같은 요인들이 안와 하벽골절에서 더 관여한다고 생각할 수 있다. 특히 안구를 지지하는 인대의 손상이나 전위가 있는 경우 안와 조직의 탈출용적에 관계 없이 안구함몰이 심하게 생길 수 있으므로 ${ }^{3)}$ 안와 하벽골절 의 경우 비록 수술의 적응 증상이 없고 전산화단층챨영상 안와용적의 증가가 작더라도 특히 안구함몰에 주의를 기울 여서 관찰해야 할 것이다.

본 연구에서는 안구돌출 계측검사를 적정한 수술 시기인 수상 후 7 14일 이전에 주로 시행하였다. 따라서 안구함몰 의 측정이 수상 초기의 급성기에 이루어져 향후 안와내 부 종의 소실 및 조직의 섬유화로 인해 증가할 수 있는 안구함 몰의 정도를 반영하지 못하여 $1.2 \mathrm{~mm}$ 의 평균값을 나타내었 으나 장기적으로 안구함몰의 정도가 심해질 것으로 예상된다.

안와 내벽골절에서 수술의 적응증이 있는 경우에는 안구 함몰의 정도와 상관없이 수술을 시행하여야 하며, 수술의 적 응이 되는 증상이 없는 경우에도 $12.8 \%$ 의 안와용적 증가가 있으면 수술을 적극적으로 고려해야 할 것으로 생각한다. 


\section{REFERENCES}

1) Raskin EM, Millman AL, Lubkin V, della Rocca RC, Lisman RD, Maher EA. Prediction of late enophthalmos by volumetric analysis of orbital fractures. Ophthal Plast Reconstr Surg 1998;14 (1):19-26.

2) Jeon SY, Kim C, Ma Y, Hwang E. Microsurgical intranasal reconstruction of blowout fractures of the medial orbital wall. Laryngoscope 1996;106 (7):910-3.

3) Manson PN, Grivas A, Rosenbaum A, Vannier M, Zinreich J, Iliff N. Studies on enophthalmos: II. The measurement of orbital injuries and their treatment by quantitative computed tomography. Plast Reconstr Surg 1986;77 (2):203-14.

4) Dulley B, Fells P. Long-term follow up of orbital blow-out fracture with and without surgery. Mod Probl Ophthalmol 1975;14:467-70.

5) Jackson IT. Classification and treatment of orbitozygomatic and orbitoethmoid fractures. The place of bone grafting and plate fixation. Clin Plast Surg 1989;16(1):77-91.

6) Whitehouse RW, Batterbury M, Jackson A, Noble JL. Prediction of enophthalmos by computed tomography after "blow out" orbital fracture. Br J Ophthalmol 1994;78 (8) :618-20.

7) Wilkins RB, Havins WE. Current treatment of blow-out fractures.
Ophthalmology 1982;89(5) :464-6.

8) Mathog RH. Management of orbital blow-out fractures. Otolaryngol Clin North Am 1991;24 (1):79-91.

9) Ploder O, Klug C, Voracek M, Burggasser G, Czerny C. Evaluation of computer-based area and volume measurement from coronal computed tomography scans in isolated blowout fractures of the orbital floor. J Oral Maxillofac Surg 2002;60 (11):1267-72; discussion 1273-4.

10) Jin HR, Shin SO, Choo MJ, Choi YS. Relationship between the extent of fracture and the degree of enophthalmos in isolated blowout fractures of the medial orbital wall. J Oral Maxillofac Surg 2000;58 (6) :617-20; discussion 620-1.

11) Bite U, Jackson IT, Forbes GS, Gehring DG. Orbital volume measurements in enophthalmos using three dimensional CT imaging. Plast Reconstrr Surg 1985;75(4):502-8.

12) Forbes G, Gehring DG, Gorman CA, Brennan MD, Jackson IT. Volume measurements of normal orbital structures by computed tomographic analysis. AJR Am J Roentgenol 1985;145 (1) :149-54.

13) Parsons G, Mathog RH. Orbital wall and volume relationships. Arch Otolaryngol Head Neck Surg 1988;114 (7) :743-7. 